\title{
On the variability of technological indicators in the extraction of precious metals
}

\author{
E. K. Ushakov, T.N. Alexandrova \\ Department of Mineral Processing, Saint Petersburg Mining University, Saint Petersburg, Russia
}

\begin{abstract}
: in the conditions of significant variability of processed polymetallic ores of the Akbastau Deposit, it is essential to minimize the variability of technological indicators of enrichment. Due to the multifactorial nature and non-linearity of the flotation process, the use of classical regression models does not provide the necessary level of reliability, therefore, there is a significant variability in the extraction of precious metals. To solve this problem, the paper substantiates the use of the neural network modeling methodology, which allows to estimate the variability of gold and silver extraction depending on the variation of the content of metals in the ore.
\end{abstract}

\section{Introduction}

Traditionally, the problem of variability is solved by calculating the regression dependence between the parameters of the source ore and the extraction of metal, but this approach does not always lead to positive results [1-3]. Due to the multifactorial nature and non-linearity of the flotation process, the use of classical regression models does not provide the necessary level of reliability, which is why there is a significant variability in the extraction of precious metals $[4,5]$.

\section{Main part}

\subsection{Multiple regression equation}

To solve this problem, technological indicators for silver and gold in the processed ores from the Akbastau Deposit for the period from 22.01.2018 to 22.07.2018 were analyzed. The statistical array included 315 observations. Statistical estimates of the studied parameters are presented in Table 1 [6-8].

Table 1. Statistical estimates of the studied parameters.

\begin{tabular}{|c|l|c|c|c|c|}
\hline Conventional signs & \multicolumn{1}{|c|}{ Parameter } & Average & Min. & Max. & Std. dev. \\
\hline $\mathrm{aCu}$ & Content of $\mathrm{Cu}$ in ore, \% & 1.19 & 0.89 & 2.0 & 0.21 \\
\hline $\mathrm{aZn}$ & Content of $\mathrm{Zn}$ in ore, \% & 0.88 & 0.13 & 3.0 & 0.79 \\
\hline $\mathrm{aAu}$ & Content of $\mathrm{Au}$ in ore, \% & 0.70 & 0.40 & 2.1 & 0.22 \\
\hline $\mathrm{aAg}$ & Content of $\mathrm{Ag}$ in ore, \% & 15.03 & 4.30 & 55.3 & 13.60 \\
\hline $\mathrm{bCu}$ & Content of $\mathrm{Cu}$ in concentrate, \% & 16.24 & 10.39 & 20.7 & 2.46 \\
\hline
\end{tabular}




\begin{tabular}{|c|l|c|c|c|c|}
\hline $\mathrm{bZn}$ & Content of $\mathrm{Zn}$ in concentrate, \% & 4.87 & 2.57 & 9.2 & 1.31 \\
\hline $\mathrm{bAu}$ & Content of Au in concentrate, \% & 4.99 & 2.10 & 11.8 & 2.45 \\
\hline $\mathrm{bAg}$ & Content of Ag in concentrate, \% & 94.34 & 43.80 & 449.3 & 67.77 \\
\hline $\mathrm{ECu}$ & Recovery of $\mathrm{Cu}, \%$ & 87.84 & 72.44 & 97.5 & 6.39 \\
\hline $\mathrm{EZn}$ & Recovery of $\mathrm{Zn}, \%$ & 57.31 & 9.45 & 100.0 & 30.00 \\
\hline $\mathrm{EAu}$ & Recovery of $\mathrm{Au}, \%$ & 44.97 & 22.77 & 95 & 16.69 \\
\hline $\mathrm{EAg}$ & Recovery of $\mathrm{Ag}, \%$ & 48.88 & 18.47 & 88.5 & 15.94 \\
\hline $\mathrm{g}$ & Cu concentrate yield, \% & 6.51 & 4.02 & 10.4 & 1.16 \\
\hline
\end{tabular}

In the analysis of the source data, there is considerable variability in the extraction of precious metals: gold is in the range of $23-95 \%$ (the content of metal in the ore is $0.4-2.1$ $\mathrm{g} / \mathrm{t}$ ), silver in the range of $20-88 \%$ (the content of metal in the ore is $4.3-55.3 \mathrm{~g} / \mathrm{t}$ ) [9]

The correlation matrix for the studied array is presented in Table 2.

Table 2. Correlation matrix.

\begin{tabular}{|c|c|c|c|c|c|c|c|c|c|c|c|c|c|}
\hline & $\mathrm{g}$ & $\mathrm{aCu}$ & $\mathrm{aZn}$ & $\mathrm{aAu}$ & $\mathrm{aAg}$ & $\mathrm{bCu}$ & $\mathrm{bZn}$ & $\begin{array}{c}\mathrm{bA} \\
\mathrm{u}\end{array}$ & $\begin{array}{c}\mathrm{bA} \\
\mathrm{g}\end{array}$ & $\begin{array}{c}\text { EC } \\
\mathrm{u}\end{array}$ & $\begin{array}{c}\text { EZ } \\
\mathrm{n}\end{array}$ & $\begin{array}{c}\text { EA } \\
\mathrm{u}\end{array}$ & $\begin{array}{c}\text { EA } \\
\text { g }\end{array}$ \\
\hline $\mathrm{g}$ & $\begin{array}{r}1.0 \\
0\end{array}$ & $\begin{array}{r}0.6 \\
9\end{array}$ & $\begin{array}{r}0.1 \\
0\end{array}$ & $\begin{array}{r}- \\
0.1 \\
0\end{array}$ & $\begin{array}{r}0.1 \\
3\end{array}$ & $\begin{array}{r}0.2 \\
5\end{array}$ & $\begin{array}{r}0.2 \\
1\end{array}$ & $\begin{array}{r}0.3 \\
0\end{array}$ & $\begin{array}{r}- \\
0.2 \\
5\end{array}$ & 0.32 & $\begin{array}{r}0.0 \\
8\end{array}$ & 0.09 & 0.25 \\
\hline $\mathrm{aCu}$ & $\begin{array}{r}0.6 \\
9\end{array}$ & $\begin{array}{r}1.0 \\
0\end{array}$ & $\begin{array}{r}0.0 \\
9\end{array}$ & $\begin{array}{r}- \\
0.1 \\
8\end{array}$ & $\begin{array}{r}0.0 \\
5\end{array}$ & $\begin{array}{r}0.4 \\
4\end{array}$ & $\begin{array}{r}- \\
0.2 \\
2\end{array}$ & $\begin{array}{r}0.2 \\
8\end{array}$ & $\begin{array}{r}0.1 \\
1\end{array}$ & 0.38 & $\begin{array}{r}0.1 \\
8\end{array}$ & 0.00 & 0.18 \\
\hline $\mathrm{aZn}$ & $\begin{array}{r}- \\
0.1 \\
0\end{array}$ & $\begin{array}{r}- \\
0.0 \\
9\end{array}$ & $\begin{array}{r}1.0 \\
0\end{array}$ & $\begin{array}{r}0.3 \\
0\end{array}$ & $\begin{array}{r}0.9 \\
3\end{array}$ & $\begin{array}{r}0.3 \\
4\end{array}$ & $\begin{array}{r}0.6 \\
0\end{array}$ & $\begin{array}{r}0.1 \\
5\end{array}$ & $\begin{array}{r}0.8 \\
2\end{array}$ & $\begin{array}{r}- \\
0.77\end{array}$ & $\begin{array}{r}0.8 \\
2\end{array}$ & $0.40^{-}$ & 0.59 \\
\hline $\mathrm{aAu}$ & $\begin{array}{r}- \\
0.1 \\
0\end{array}$ & $\begin{array}{r}- \\
0.1 \\
8\end{array}$ & $\begin{array}{r}0.3 \\
0\end{array}$ & $\begin{array}{r}1.0 \\
0\end{array}$ & $\begin{array}{r}0.3 \\
9\end{array}$ & $\begin{array}{r}- \\
0.1 \\
3\end{array}$ & $\begin{array}{r}0.1 \\
7\end{array}$ & $\begin{array}{r}0.5 \\
8\end{array}$ & $\begin{array}{r}0.3 \\
4\end{array}$ & 0.23 & $\begin{array}{r}- \\
0.1 \\
3\end{array}$ & 0.03 & 0.42 \\
\hline $\mathrm{aAg}$ & $\begin{array}{r}- \\
0.1 \\
3\end{array}$ & $\begin{array}{r}- \\
0.0 \\
5\end{array}$ & $\begin{array}{r}0.9 \\
3\end{array}$ & $\begin{array}{r}0.3 \\
9\end{array}$ & $\begin{array}{r}1.0 \\
0\end{array}$ & $\begin{array}{r}0.2 \\
2\end{array}$ & $\begin{array}{r}0.5 \\
7\end{array}$ & $\begin{array}{r}0.0 \\
7\end{array}$ & $\begin{array}{r}0.9 \\
0\end{array}$ & 0.72 & $\begin{array}{r}0.7 \\
4\end{array}$ & $0.38^{-}$ & 0.66 \\
\hline $\mathrm{bCu}$ & $\begin{array}{r}- \\
0.2 \\
5\end{array}$ & $\begin{array}{r}0.4 \\
4 \\
\end{array}$ & $\begin{array}{r}- \\
0.3 \\
4\end{array}$ & $\begin{array}{r}- \\
0.1 \\
3\end{array}$ & $\begin{array}{r}- \\
0.2 \\
2\end{array}$ & $\begin{array}{r}1.0 \\
0\end{array}$ & $\begin{array}{r}- \\
0.2 \\
5\end{array}$ & $\begin{array}{r}0.2 \\
0\end{array}$ & $\begin{array}{r}- \\
0.1 \\
3\end{array}$ & 0.50 & $\begin{array}{r}0.4 \\
5\end{array}$ & 0.16 & 0.16 \\
\hline $\mathrm{bZn}$ & $\begin{array}{r}- \\
0.2 \\
1\end{array}$ & $\begin{array}{r}- \\
0.2 \\
2\end{array}$ & $\begin{array}{r}0.6 \\
0 \\
\end{array}$ & $\begin{array}{r}0.1 \\
7 \\
\end{array}$ & $\begin{array}{r}0.5 \\
7 \\
\end{array}$ & $\begin{array}{r}- \\
0.2 \\
5\end{array}$ & $\begin{array}{r}1.0 \\
0 \\
\end{array}$ & $\begin{array}{r}0.0 \\
5 \\
\end{array}$ & $\begin{array}{r}0.5 \\
1 \\
\end{array}$ & 0.51 & $\begin{array}{r}- \\
0.3 \\
5\end{array}$ & 0.26 & 0.39 \\
\hline $\mathrm{bAu}$ & $\begin{array}{r}- \\
0.3 \\
0\end{array}$ & $\begin{array}{r}- \\
0.2 \\
8\end{array}$ & $\begin{array}{r}- \\
0.1 \\
5\end{array}$ & $\begin{array}{r}0.5 \\
8\end{array}$ & $\begin{array}{r}- \\
0.0 \\
7\end{array}$ & $\begin{array}{r}0.2 \\
0\end{array}$ & $\begin{array}{r}- \\
0.0 \\
5\end{array}$ & $\begin{array}{r}1.0 \\
0\end{array}$ & $\begin{array}{r}- \\
0.0 \\
1\end{array}$ & 0.25 & $\begin{array}{r}0.4 \\
1\end{array}$ & 0.74 & 0.05 \\
\hline $\mathrm{bAg}$ & $\begin{array}{r}- \\
0.2 \\
5\end{array}$ & $\begin{array}{r}0.1 \\
1\end{array}$ & $\begin{array}{r}0.8 \\
2\end{array}$ & $\begin{array}{r}0.3 \\
4\end{array}$ & $\begin{array}{r}0.9 \\
0\end{array}$ & $\begin{array}{r}- \\
0.1 \\
3\end{array}$ & $\begin{array}{r}0.5 \\
1\end{array}$ & $\begin{array}{r}- \\
0.0 \\
1\end{array}$ & $\begin{array}{r}1.0 \\
0\end{array}$ & 0.67 & $\begin{array}{r}- \\
0.6 \\
7\end{array}$ & 0.32 & 0.48 \\
\hline $\mathrm{ECu}$ & $\begin{array}{r}0.3 \\
2\end{array}$ & $\begin{array}{r}0.3 \\
8\end{array}$ & $\begin{array}{r}- \\
0.7 \\
7\end{array}$ & $\begin{array}{r}- \\
0.2 \\
3\end{array}$ & $\begin{array}{r}- \\
0.7 \\
2\end{array}$ & $\begin{array}{r}0.5 \\
0\end{array}$ & $\begin{array}{r}- \\
0.5 \\
1\end{array}$ & $\begin{array}{r}0.2 \\
5\end{array}$ & $\begin{array}{r}- \\
0.6 \\
7\end{array}$ & 1.00 & $\begin{array}{r}0.7 \\
7\end{array}$ & 0.56 & 0.56 \\
\hline EZn & $\begin{array}{r}0.0 \\
8\end{array}$ & $\begin{array}{r}0.1 \\
8\end{array}$ & $\begin{array}{r}- \\
0.8 \\
2\end{array}$ & $\begin{array}{r}- \\
0.1 \\
3\end{array}$ & $\begin{array}{r}0.7 \\
4\end{array}$ & $\begin{array}{r}0.4 \\
5\end{array}$ & $\begin{array}{r}- \\
0.3 \\
5\end{array}$ & $\begin{array}{r}0.4 \\
1\end{array}$ & $\begin{array}{r}0.6 \\
7\end{array}$ & 0.77 & $\begin{array}{r}1.0 \\
0\end{array}$ & 0.56 & 0.52 \\
\hline $\begin{array}{c}\text { EA } \\
\mathrm{u}\end{array}$ & $\begin{array}{r}0.0 \\
9\end{array}$ & $\begin{array}{r}0.0 \\
0\end{array}$ & $\begin{array}{r}- \\
0.4 \\
0\end{array}$ & $\begin{array}{r}0.0 \\
3\end{array}$ & $\begin{array}{r}- \\
0.3 \\
8\end{array}$ & $\begin{array}{r}0.1 \\
6\end{array}$ & $\begin{array}{r}- \\
0.2 \\
6\end{array}$ & $\begin{array}{r}0.7 \\
4\end{array}$ & $\begin{array}{r}- \\
0.3 \\
2\end{array}$ & 0.56 & $\begin{array}{r}0.5 \\
6\end{array}$ & 1.00 & 0.48 \\
\hline $\begin{array}{c}\text { EA } \\
\mathrm{g}\end{array}$ & $\begin{array}{r}0.2 \\
5 \\
\end{array}$ & $\begin{array}{r}0.1 \\
8 \\
\end{array}$ & $\begin{array}{r}0.5 \\
9\end{array}$ & $\begin{array}{r}0.4 \\
2 \\
\end{array}$ & $\begin{array}{r}0.6 \\
6 \\
\end{array}$ & $\begin{array}{r}0.1 \\
6 \\
\end{array}$ & $\begin{array}{r}0.3 \\
9 \\
\end{array}$ & $\begin{array}{r}0.0 \\
5 \\
\end{array}$ & $\begin{array}{r}0.4 \\
8 \\
\end{array}$ & 0.56 & $\begin{array}{r}0.5 \\
2 \\
\end{array}$ & 0.48 & 1.00 \\
\hline
\end{tabular}


The correlation matrix shows a negative correlation between the content of precious metals in the ore and their extraction into the copper concentrate $[10,11]$. At the same time, there is a strong positive correlation between the metal content in the ore and in the copper concentrate, which is also quite evident in the trends shown in Figures 1 and 2.

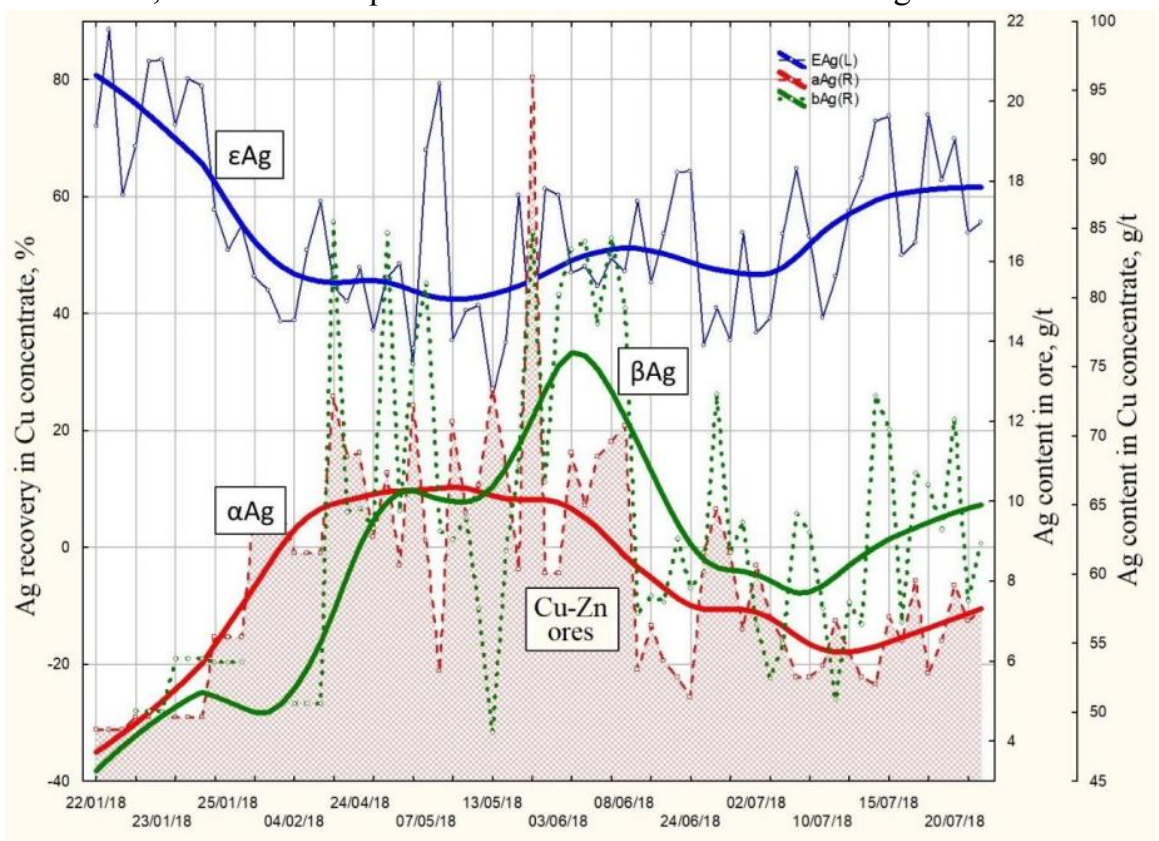

Fig. 1. Trends in the dynamics of changes in technological indicators for silver.

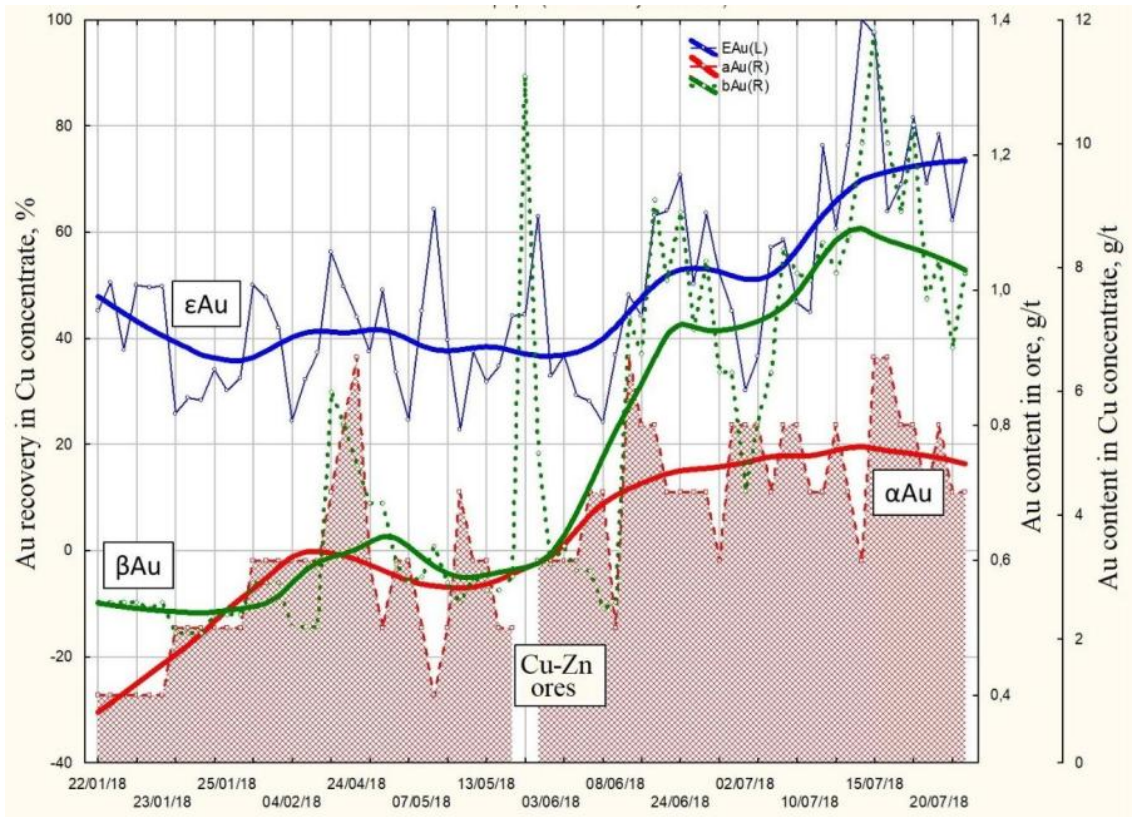

Fig. 2. Trends in the dynamics of changes in technological indicators for gold. 
The dispersion of values in the graph in Figure 3 show the difficulty in identifying the causes of significant variability in the extraction of precious metals.

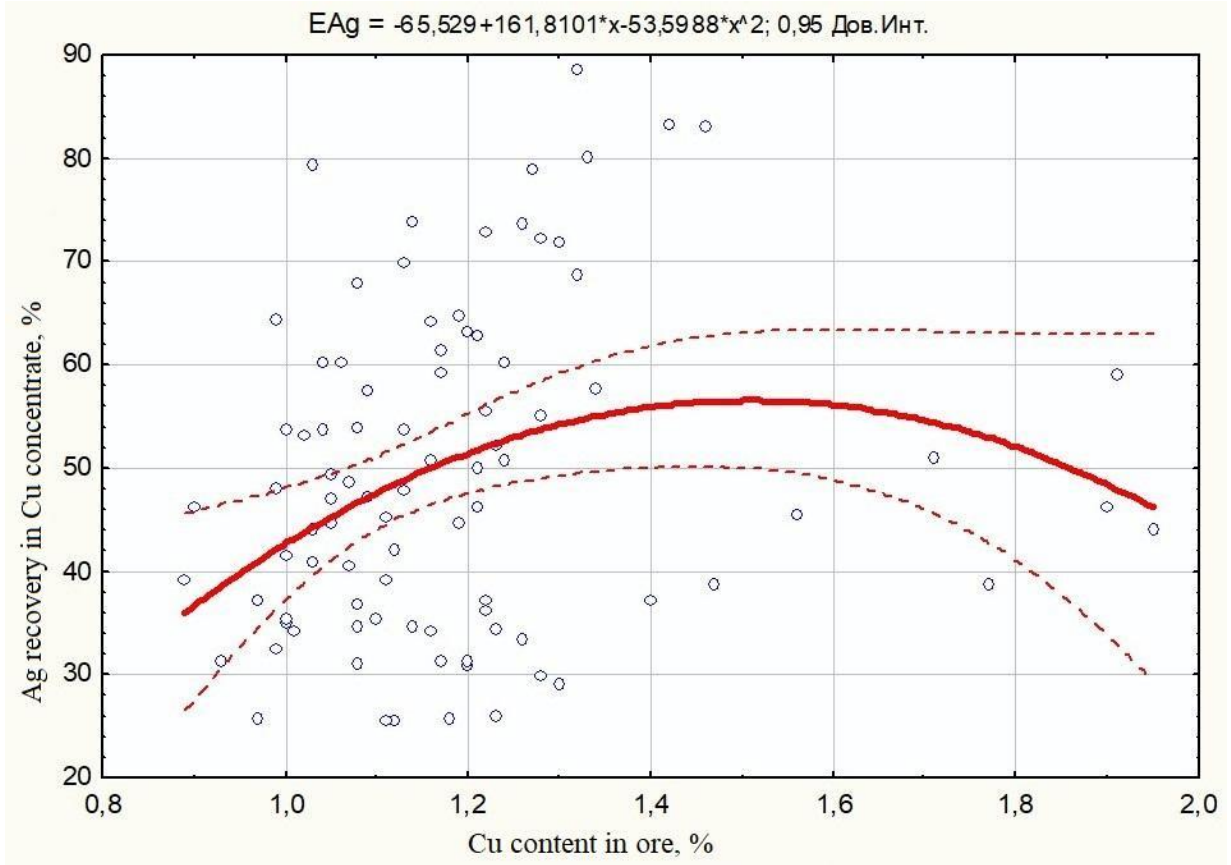

Fig. 3. Dependency of silver extraction from the variation of copper content in the ore.

An attempt was made to classically calculate the multiple regression equation, the results of which are presented in Table 3.

Table 3. The results of the regression for the extraction of silver.

\begin{tabular}{|c|c|c|c|c|c|c|}
\hline & BETA & S.E.M & B & S.E.M & $\mathrm{t}(85)$ & p-equation \\
\hline Constant term & & & 54.1991 & 9.347510 & 5.79824 & 0.000000 \\
\hline $\mathrm{aCu}$ & 0.133638 & 0.080486 & 10.3314 & 6.222296 & 1.66038 & 0.100522 \\
\hline $\mathrm{aZn}$ & 0.198072 & 0.226928 & 3.9898 & 4.571064 & 0.87284 & 0.385211 \\
\hline $\mathrm{aAu}$ & -0.145069 & 0.088430 & -10.5566 & 6.435048 & -1.64049 & 0.104598 \\
\hline $\mathrm{aAg}$ & -0.779972 & 0.235035 & -0.9142 & 0.275472 & -3.31854 & 0.001334 \\
\hline
\end{tabular}

The term "BETA" refers to the equation's regression coefficients on a standardized scale, i.e., according to Equation 1.

$$
\varepsilon=0.13 \alpha \mathrm{Cu}+0.2 \alpha \mathrm{Zn}-0.15 \alpha \mathrm{Au}-0.78 \alpha \mathrm{Ag} \text {. }
$$

Based on the values of standardized coefficients, we can make a conclusion. The silver content in the ore, compared to the content of other elements in the ore, significantly affects the extraction of silver. The influence of other elements on the output function is not significant, according to Kolmogorov's criterion [12]. Moreover, the negative correlation between the content of silver in the ore and the extraction of metal is technologically difficult to explain.

The designation "B" refers to the natural values of the coefficients in the regression equation, i.e., the calculated equation is represented as Equation 2.

$$
\varepsilon=54.2+10.3 \alpha \mathrm{Cu}+3.99 \alpha \mathrm{Zn}-10.6 \alpha \mathrm{Au}-0.91 \alpha \mathrm{Ag}
$$

However, the low value of the multiple regression coefficient of the resulting equation $\mathrm{R}=0.69$ should be specifically noted.

The information estimate of the obtained model is $\mathrm{H}=\mathrm{R}^{2}=0.46$, i.e., $46 \%$. 
Thus, we can conclude that it is rather unpromising to use classical regression models for flotation.

\subsection{Neural network modeling}

In regard to the studied array, the neural network model GRNN 4:4-46-2-1:1 (8) was calculated, the architecture of which is presented in Table 4 [13].

The output function is extraction of silver. Input variables are marked in the table of sensitivity of output functions to variations of initial features (Table 5). Statistical estimates of the model are presented in Table 6.

Table 4. Architecture of the GRNN 4:4-46-2-1:1 (8) neural network model.

\begin{tabular}{|c|c|c|c|c|c|c|c|c|c|}
\hline $\begin{array}{c}\text { Architectu } \\
\text { re }\end{array}$ & $\begin{array}{c}\text { Learnin } \\
\mathrm{g} \\
\text { efficienc } \\
\mathrm{y}\end{array}$ & $\begin{array}{c}\text { Control } \\
\text { efficienc } \\
\mathrm{y}\end{array}$ & $\begin{array}{c}\text { Test } \\
\text { efficienc } \\
\mathrm{y}\end{array}$ & $\begin{array}{c}\text { Learnin } \\
\mathrm{g} \text { errors }\end{array}$ & $\begin{array}{c}\text { Contr } \\
\text { ol } \\
\text { error }\end{array}$ & $\begin{array}{c}\text { Test } \\
\text { error }\end{array}$ & $\begin{array}{c}\text { Input } \\
\mathrm{s}\end{array}$ & $\begin{array}{c}\text { Hidde } \\
\mathrm{n}(1)\end{array}$ & $\begin{array}{c}\text { Hidde } \\
\mathrm{n}(2)\end{array}$ \\
\hline $\begin{array}{c}\text { GRNN } \\
\begin{array}{c}4: 4-46-2- \\
1: 1\end{array}\end{array}$ & 0.600 & 0.563 & 0.638 & 0.035 & 0.033 & $\begin{array}{c}0.02 \\
6\end{array}$ & 4 & 46 & 2 \\
\hline
\end{tabular}

Table 5. Sensitivity of the output function to variations in the initial features.

\begin{tabular}{|c|c|c|c|c|}
\hline Functions & $\mathrm{aCu}$ & $\mathrm{aZn}$ & $\mathrm{aAu}$ & $\mathrm{aAg}$ \\
\hline Correlation & 1.139 & 1.280 & 1.167 & 1.201 \\
\hline Rank & 4 & 1 & 3 & 2 \\
\hline
\end{tabular}

The results of the analysis of the sensitivity of the output function to variations in the initial characteristics show that the greatest influence on the variability of silver extraction is the variation in the content of zinc in the ore.

Table 6. Statistical estimates of the GRNN 4:4-46-2-1:1 (8) model.

\begin{tabular}{|l|c|}
\hline Statistical estimations & Value \\
\hline Average & 48.88 \\
\hline St. dev. & 15.85 \\
\hline Average error mean & -0.254 \\
\hline Standard deviation of error & 9.363 \\
\hline Mean absolute error & 7.328 \\
\hline Correlation & 0.820 \\
\hline
\end{tabular}

The adequacy of the obtained model is estimated by the correlation coefficient $\mathrm{R}=0.82$.

The neural network model allows to obtain generalized response functions, i.e., an evaluation of the variability of silver extraction based on the variation in the content of metals in the ore (Fig. 4-6). The curves shown in the figures are described by the equations shown in the figure captions. 


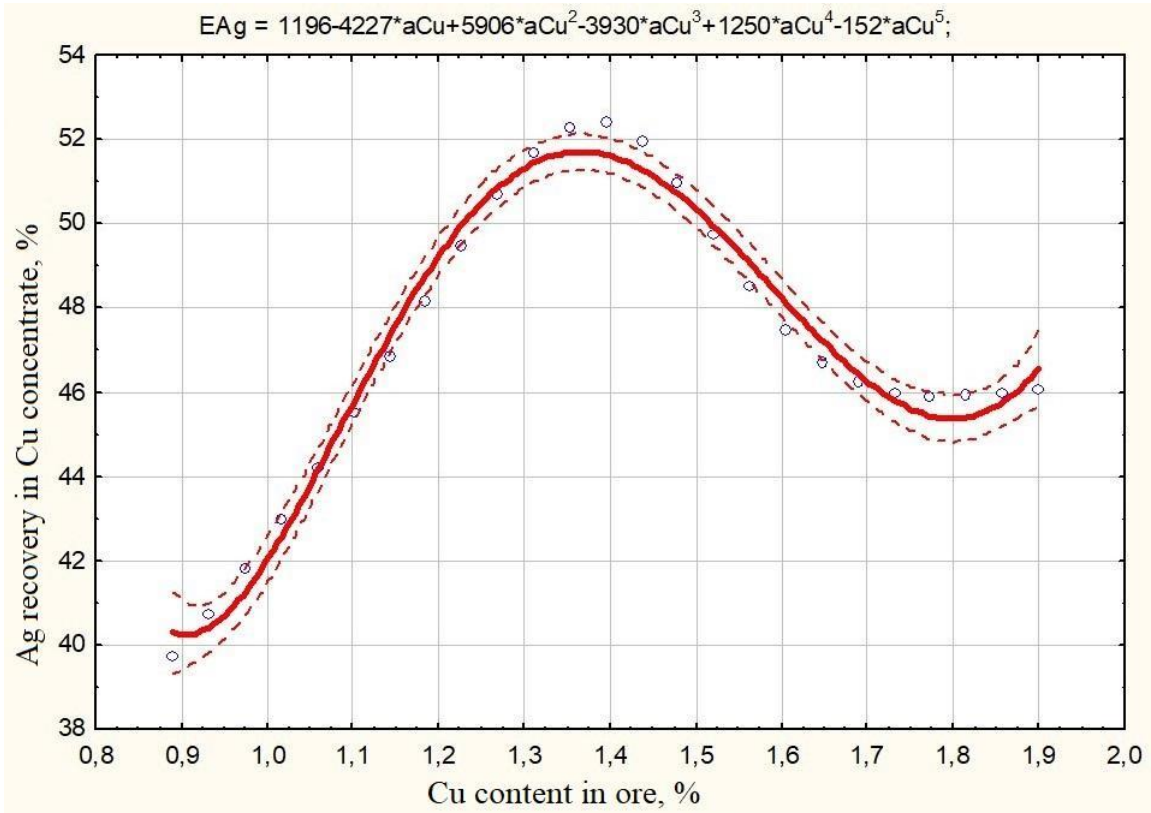

Fig. 4. Estimation of the variability of silver extraction from the variation of the copper content in the ore.

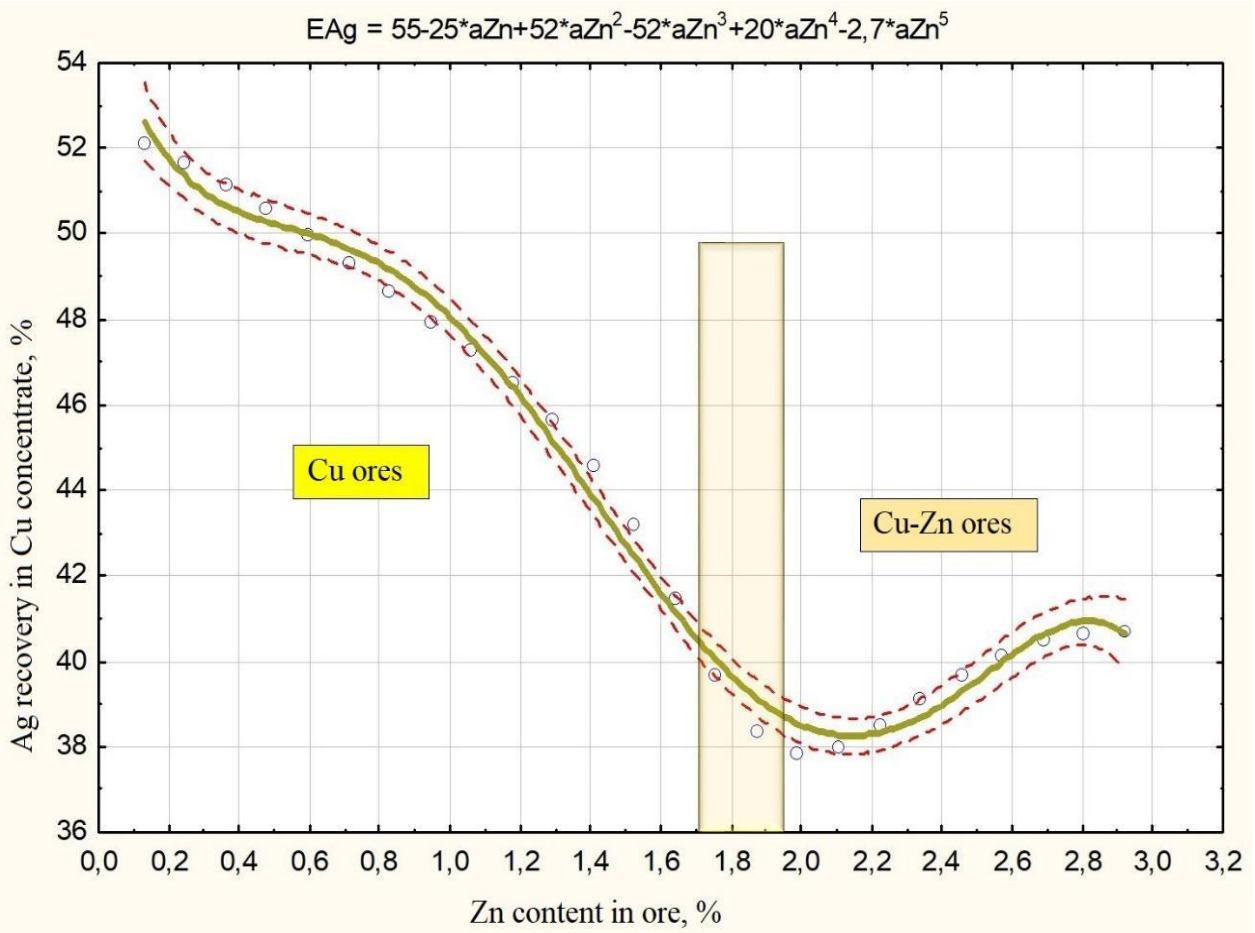

Fig. 5. Estimation of the variability of silver extraction from the variation of the zinc content in the ore. 


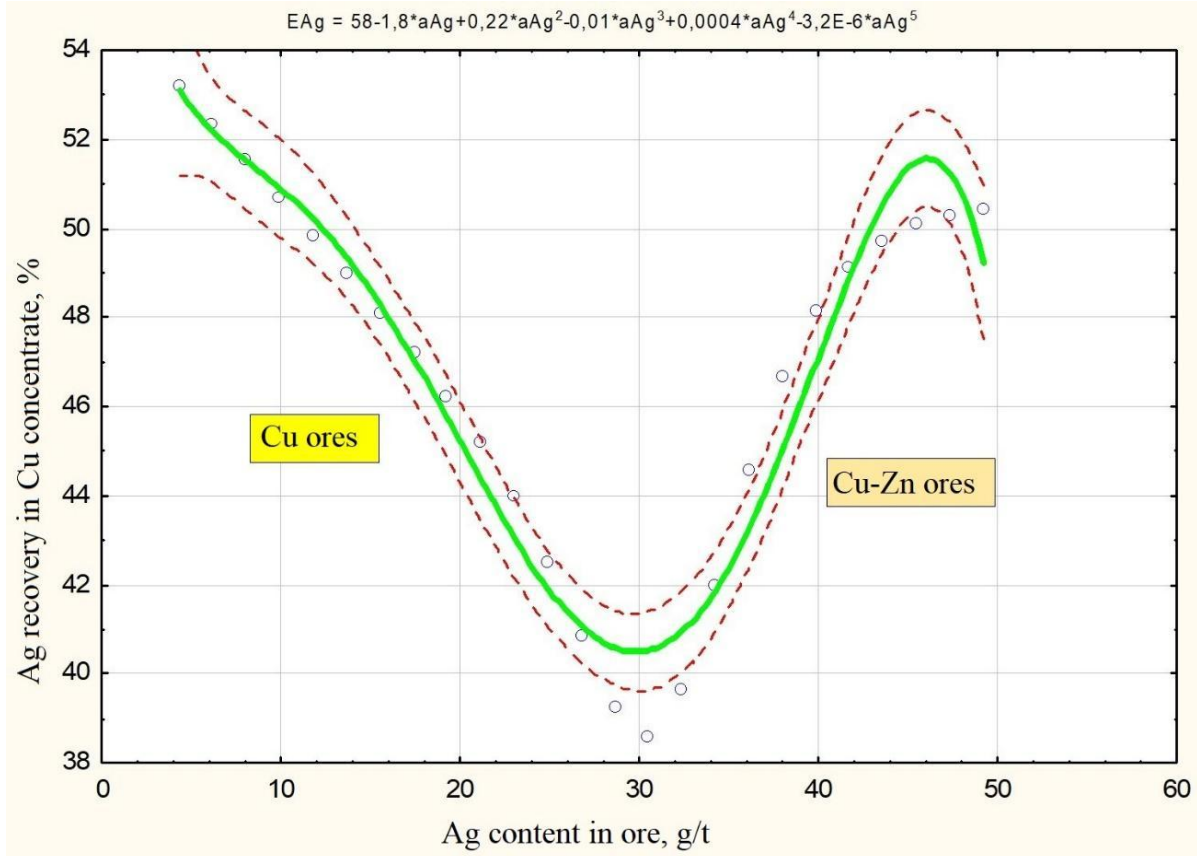

Fig. 6. Estimation of the variability of silver extraction from the variation of the silver content in the ore.

The decrease in silver extraction with an increase in the copper content in the ore is higher (Fig. 4) is probably due to the increased sulfide content and the development of electrochemical corrosion processes in the ore body [14].

The function of the silver extraction reaction to the variation of the zinc content in the ore (Fig. 5) clearly reflects the presence of observations of copper and copper-zinc ores in the initial statistical array.

The function of the silver extraction reaction to the variation of the silver content in the ore (Fig. 6) shows that copper ores are characterized by a decrease in the extraction of silver into the copper concentrate with an increase of the silver content in the ore. This observation requires additional research. For copper-zinc ores, the classical dependence $\varepsilon \mathrm{Ag}=\mathrm{f}(\alpha \mathrm{Ag})$ was observed.

The results of the calculation of the multiple regression equation for gold recovery are presented in Table 7.

Table 7. The results of the regression for the extraction of gold.

\begin{tabular}{|c|c|c|c|c|c|c|}
\hline & BETA & S.E.M & B & S.E.M & $\mathrm{t}(85)$ & p-equation \\
\hline Constant term & & & 43.61820 & 12.19678 & 3.576206 & 0.000578 \\
\hline $\mathrm{aCu}$ & -0.003342 & 0.100326 & -0.27045 & 8.11895 & -0.033311 & 0.973505 \\
\hline $\mathrm{aZn}$ & -0.253528 & 0.282865 & -5.34581 & 5.96440 & -0.896286 & 0.372631 \\
\hline $\mathrm{aAu}$ & 0.197432 & 0.110228 & 15.03930 & 8.39655 & 1.791128 & 0.076832 \\
\hline $\mathrm{aAg}$ & -0.224496 & 0.292969 & -0.27543 & 0.35944 & -0.766280 & 0.445633 \\
\hline
\end{tabular}

Equation 3 on a standardized scale shows that the parameters of the source ore do not affect the extraction of gold.

$$
\varepsilon=-0.003 \alpha \mathrm{Cu}-0.25 \alpha \mathrm{Zn}+0.2 \alpha \mathrm{Au}-0.22 \alpha \mathrm{Ag} .
$$

On a natural scale, the form of Equation 3 accords with Equation 4:

$$
\varepsilon=43.6-0.27 \alpha \mathrm{Cu}-5.35 \alpha \mathrm{Zn}+15 \alpha \mathrm{Au}-0.28 \alpha \mathrm{Ag} \text {. }
$$


Thus, the regression equation on a standardized scale shows no influence of the initial ore parameters on gold extraction (according to Kolmogorov's criterion) [15]. Due to that, an MLP 4:4-10-5-1:1 (10) neural network model (multi-layer perceptron) was calculated for the studied array, the architecture of which is shown in Table 8 .

The output function is extraction of gold. Input variables are marked in the table of sensitivity of output functions to variations of initial features (Table 5). Statistical estimates of the model are presented in Table 10.

Table 8. Architecture of the MLP 4:4-10-5-1: 1 (10) neural network model.

\begin{tabular}{|c|c|c|c|c|c|c|c|c|c|}
\hline $\begin{array}{c}\text { Architectu } \\
\text { re }\end{array}$ & $\begin{array}{c}\text { Learnin } \\
\mathrm{g} \\
\text { efficienc } \\
\mathrm{y}\end{array}$ & $\begin{array}{c}\text { Control } \\
\text { efficienc } \\
\mathrm{y}\end{array}$ & $\begin{array}{c}\text { Test } \\
\text { efficienc } \\
\mathrm{y}\end{array}$ & $\begin{array}{c}\text { Learnin } \\
\mathrm{g} \text { errors }\end{array}$ & $\begin{array}{c}\text { Contr } \\
\text { ol } \\
\text { error }\end{array}$ & $\begin{array}{c}\text { Test } \\
\text { error }\end{array}$ & $\begin{array}{c}\text { Input } \\
\mathrm{s}\end{array}$ & $\begin{array}{c}\text { Hidde } \\
\mathrm{n}(1)\end{array}$ & $\begin{array}{c}\text { Hidde } \\
\mathrm{n}(2)\end{array}$ \\
\hline $\begin{array}{c}\text { MLP 4:4- } \\
10-5-1: 1\end{array}$ & 0.533 & 0.832 & 1.119 & 0.110 & 0.203 & $\begin{array}{c}0.22 \\
0\end{array}$ & 4 & 10 & 5 \\
\hline
\end{tabular}

Table 9. Sensitivity of the output function to variations in the initial features.

\begin{tabular}{|c|c|c|c|c|}
\hline Functions & $\mathrm{aCu}$ & $\mathrm{aZn}$ & $\mathrm{aAu}$ & $\mathrm{aAg}$ \\
\hline Correlation & 1,457 & 1,271 & 1,162 & 1,354 \\
\hline Rank & $\mathbf{1}$ & 3 & 4 & 2 \\
\hline
\end{tabular}

The results of the analysis of the sensitivity of the output function to variations in the initial characteristics show that a variation in the content of copper in the ore has the greatest influence on the variability of gold recovery.

Table 10. Statistical estimates of the MLP model 4:4-10-5-1:1 (10).

\begin{tabular}{|l|l|}
\hline Statistical estimations & EAu \\
\hline Average & 45.0 \\
\hline St. dev. & 16.6 \\
\hline Average error mean & 1.371 \\
\hline Standard deviation of error & 12.88 \\
\hline Mean absolute error & 9.710 \\
\hline Correlation & 0.660 \\
\hline
\end{tabular}

The adequacy of the obtained model is evaluated by the correlation coefficient $\mathrm{R}=0.82$.

The neural network model allows to obtain generalized response functions, i.e., an evaluation of the variability of gold extraction based on the variation in the content of metals in the ore (Fig. 7-9). The curves shown in the figures are described by the equations shown in the figure captions. 


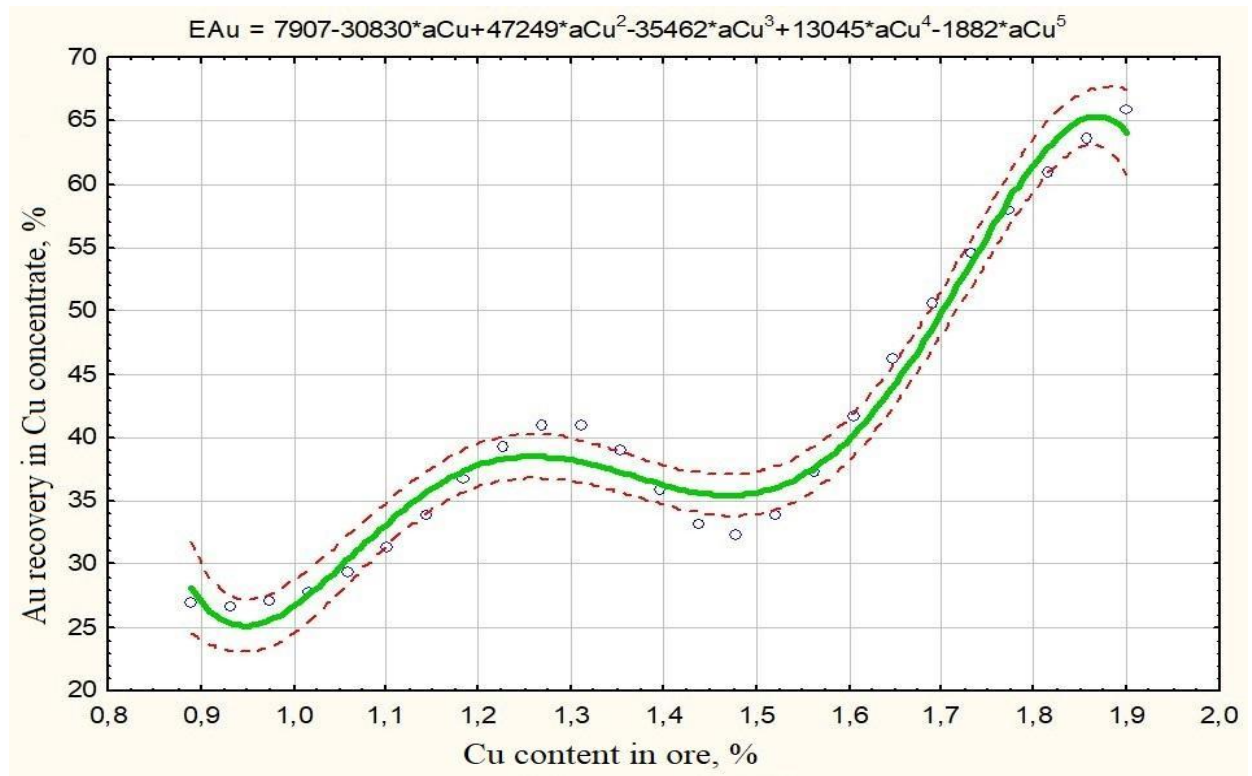

Fig. 7. Estimation of the variability of gold extraction based on the variation of the copper content in the ore.

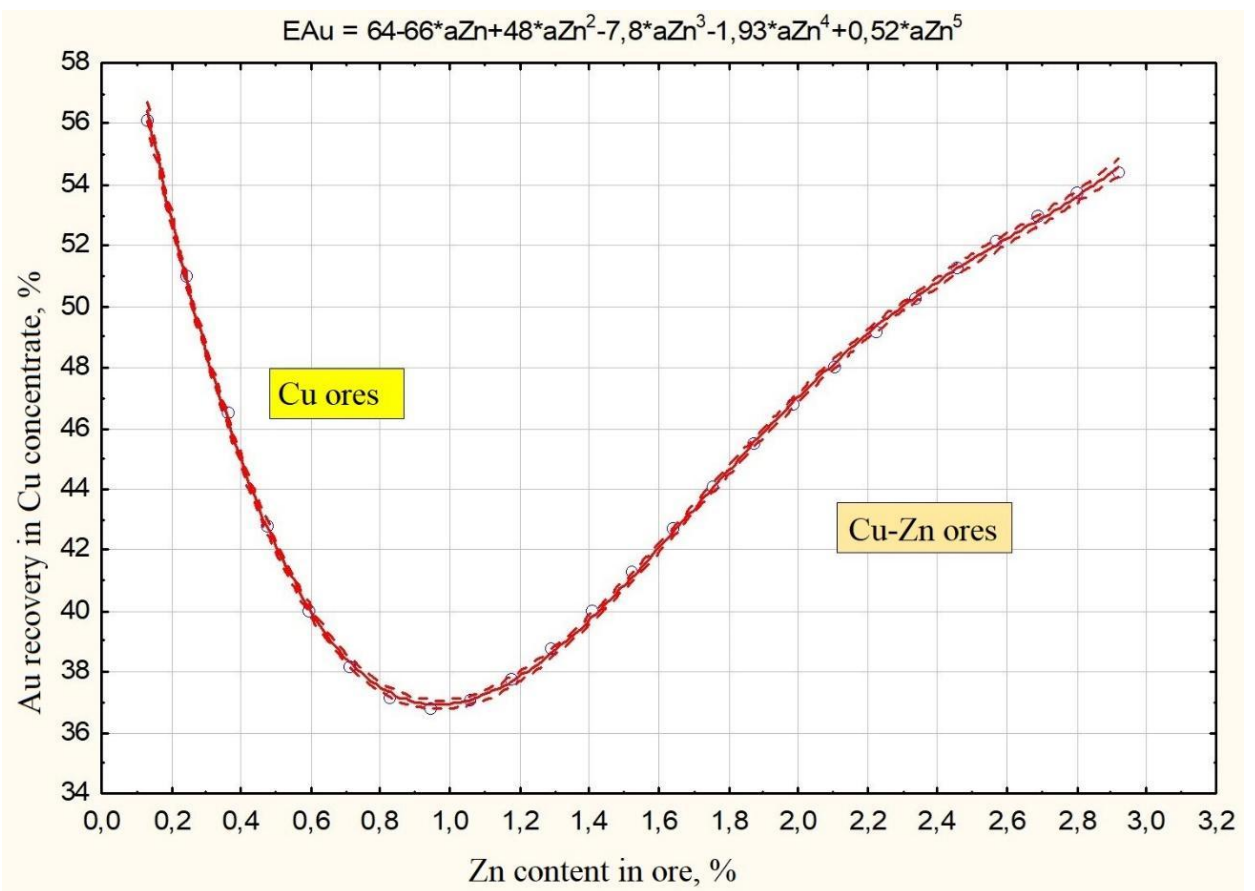

Fig. 8. Estimation of the variability of gold extraction based on the variation of the zinc content in the ore. 


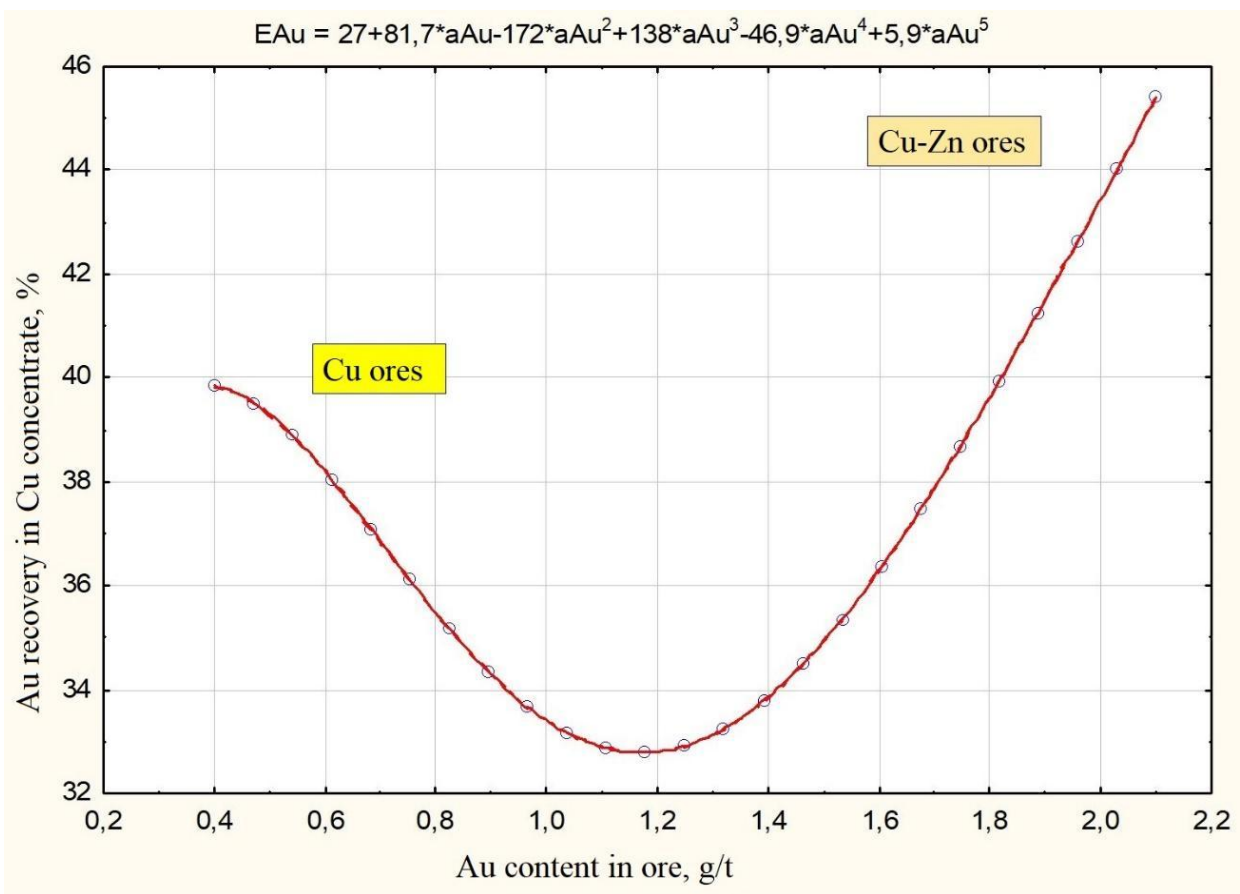

Fig. 9. Estimation of the variability of gold extraction based on the variation of the gold content in the ore.

The function of the reaction of gold extraction to the variation in the zinc content in the ore (Fig. 8) clearly reflects the presence of observations of copper and copper-zinc ores in the initial statistical array.

The function of reaction of gold extraction to the variation of gold content in the ore (Fig. 9) shows that a decrease in gold extraction in the copper concentrate with increased gold content in the ore is typical for copper ores, like as it was with silver. This observation requires additional research and may be a consequence of the genetic features of the deposit. For copper-zinc ores, the classical dependence $\varepsilon A u=f(\alpha A u)$ was observed.

\subsection{Laboratory tests}

Based on the results of this study, a series of experiments in controlled conditions were conducted. The experiments consider the operation regime of a plant that processes ore from Akbastau in order to assess the variability of technological indicators based on the variation of the content of useful elements in the ore. For this task, 5 ore samples with different metal content were taken from this deposit. The chemical composition of the samples is shown in Table 11. Technological indicators of enrichment for a series of experiments are presented in Table 12.

Table 11. Chemical composition of initial sample.

\begin{tabular}{|c|c|c|c|c|c|}
\hline Content & \multicolumn{5}{|c|}{ Designation of sample } \\
\hline & Sample 1 & Sample 2 & Sample 3 & Sample 4 & Sample 5 \\
\hline Cu. \% & 0.92 & 0.97 & 1.16 & 1.42 & 1.54 \\
\hline Zn. \% & 0.94 & 0.89 & 1.42 & 0.57 & 0.23 \\
\hline Au. $\Gamma / \mathrm{T}$ & 1.08 & 1.24 & 1.74 & 0.42 & 2.07 \\
\hline Ag. $\Gamma / \mathrm{T}$ & 29.34 & 35.7 & 38.37 & 10.04 & 37.62 \\
\hline
\end{tabular}


Table 12. Technological indicators of enrichment.

\begin{tabular}{|l|c|c|c|c|c|c|c|c|c|}
\hline $\begin{array}{c}\text { Designation } \\
\text { of sample }\end{array}$ & $\begin{array}{c}\mathrm{Cu} \\
\text { concentrate } \\
\text { yield, \% }\end{array}$ & \multicolumn{4}{|c|}{ Content in concentrate, \% } & \multicolumn{3}{c|}{ Recovery in concentrate, \% } \\
\hline & & $\begin{array}{c}\mathrm{Cu}, \\
\%\end{array}$ & $\begin{array}{c}\mathrm{Zn}, \\
\%\end{array}$ & $\begin{array}{c}\mathrm{Au}, \\
\Gamma / \mathrm{T}\end{array}$ & $\begin{array}{c}\mathrm{Ag}, \\
\Gamma / \mathrm{T}\end{array}$ & $\begin{array}{c}\mathrm{Cu}, \\
\%\end{array}$ & $\begin{array}{c}\mathrm{Zn}, \\
\%\end{array}$ & $\begin{array}{c}\mathrm{Au}, \\
\%\end{array}$ & $\begin{array}{c}\mathrm{Ag}, \\
\%\end{array}$ \\
\hline Sample 1 & 5.59 & 12.70 & 5.26 & 5.84 & 200.34 & 77.18 & 31.29 & 30.24 & 38.17 \\
\hline Sample 2 & 5.68 & 13.53 & 5.04 & 6.99 & 271.14 & 79.24 & 32.14 & 32.01 & 43.14 \\
\hline Sample 3 & 5.91 & 14.96 & 9.17 & 11.79 & 307.02 & 76.24 & 38.17 & 40.06 & 47.29 \\
\hline Sample 4 & 6.40 & 18.59 & 2.75 & 2.75 & 81.40 & 83.79 & 30.85 & 41.97 & 51.89 \\
\hline Sample 5 & 6.67 & 19.59 & 2.12 & 10.61 & 264.92 & 84.86 & 61.40 & 34.19 & 46.97 \\
\hline
\end{tabular}

According to the obtained data presented in Table 12, it can be concluded that significant variability of technological indicators was observed for these samples. There is a correlation between the variability of the obtained technological indicators and the variation of useful components in the initial ore, according to the estimates described in the course of theoretical research using neural network modeling. For laboratory-obtained extraction indicators and those obtained by neural network modeling, the correlation value $\mathrm{R}$ amounts to 0.77 and 0.90 for gold and silver, respectively.

\section{Conclusion}

The failure of the classical approach in estimating the variability of recovery of precious metals by calculating multiple regression equations was shown. The most effective way to describe the complex multifactorial nature and non-linear character of the flotation objects is to use the neural network modeling methodology. Relatively high correlation values of the extraction of precious metals obtained in laboratory conditions with the theoretical extraction, which was calculated using the method of neural network modeling, were found.

The work was funded by Russian Science Foundation (Project No. 19-17-00096).

\section{References}

1. A.T. Beriashvili, V.M. Pikulina, A new approach to solving the problem of variable copper recovery at the example of the Zhezkazgan ore field. Obogashchenie Rud. 5. 40-44 (2018).

2. T.N. Alexandrova, Key directions in processing carbonaceous rocks. Zapiski Gornogo instituta, 220, 568-572 (2016).

3. E. Alekseeva, V.N. Brichkin, N. Nikolaeva, A. Romashev, Application of sensor-based sorting for beneficiation of low-grade mineral resources. International Multidisciplinary Scientific GeoConference Surveying Geology and Mining Ecology Management, SGEM. 3(1), 823-829 (2014).

4. T.D. Kalmykova, A.O. Romashev, Revising the initialization of the kinetic models for flotation of carbonaceous raw materials. Topical Issues of Rational Use of Natural Resources 2019. 2, 517-524 (2020).

5. T. Kohonen, Associative memory (Moscow: Mir, 1980).

6. A. Duryagina, G. Heide, I. Talovina, A. Bravo, Mineralogical and morphometric aspects of the rock analysis as the basis for choosing a scheme for ore preparation. E3S Web of Conference, 192, 02023 (2020) 
7. T. Kohonen, Self-Organizing Maps: Adaptive and Intelligent Systems (M.: BINOM. Laboratory of knowledge, 2010).

8. T.J. Napier-Munn, Statistical methods for mineral engineers - How to design experiments and analyze data. (Queensland. Australia: Julius Kruttschnitt Mineral Research Centre, 2014).

9. N.V. Nikolaeva, V.A. Taranov, A.V. Afanasova, Ore strength analysis in planning ore pretreatment circuit Gornyi Zhurnal, 12, 9-13 (2015).

10. A.V. Arustamyan M.A. Solovyova et al. Classification of the technological flotation concentration schemes of pyrite-copper and copper-zinc ores. Gornyi Zhurnal. Issue, 11, 28-33. (2012).

11. S. Kheikkinen, G.N. Mashevskiy Algorithmic framework for the control of the flotation process. Obogashchenie rud. 6, 32-37 (2005)

12. G.N. Mashevskiy, S.A. Romanenko, Copper-pyrite ores flotation cleaning cycle mathematical model. Obogashchenie Rud. 2, 23-27 (2014).

13. G.N. Mashevskiy, A.M. Kokorin, Development of scientific bases for improving the technology and creating an algorithmic base for computer control of flotation of ores of the Erdenetiyn Ovoo Deposit with the aim of improving the profitability of production. Collection of reports of NTS JV "Erdenet". Publishing House "Erdenet concern,. 87101 (1998).

14. G.N. Mashevskiy, A.V. Petrov, S.A. Romanenko, F. S. Sufianov, Development of Kuznetsov V.V. Elevation of gold-bearing sulphide flotation efficiency. Topical Issues of Rational Use of Natural Resources 2019, 2, 541-545 (2020) 